Article

\title{
Toward Sustainable Learning during School Suspension: Socioeconomic, Occupational Aspirations, and Learning Behavior of Vietnamese Students during COVID-19
}

\author{
Trung Tran ${ }^{1}$, Anh-Duc Hoang 2,*, Yen-Chi Nguyen ${ }^{2}$, Linh-Chi Nguyen ${ }^{2}$, Ngoc-Thuy Ta ${ }^{2}$, \\ Quang-Hong Pham ${ }^{3}$, Chung-Xuan Pham ${ }^{4}$, Quynh-Anh Le ${ }^{2}$, \\ Viet-Hung Dinh ${ }^{5}$ and Tien-Trung Nguyen ${ }^{6}$ \\ 1 Department of Basic, Vietnam Academy for Ethnic Minorities, Hanoi 100000, Vietnam; \\ trantrung@cema.gov.vn \\ 2 EdLab, Asia Educational Research and Development Centre, Hanoi 100000, Vietnam; \\ chi@edlabasia.org (Y.-C.N.); linhchi@edlabasia.org (L.-C.N.); thuyta@edlabasia.org (N.-T.T.); \\ quynhanh@edlabasia.org (Q.-A.L.) \\ 3 Faculty of Psychology and Pedagogy, Thai Nguyen University of Education, \\ Thai Nguyen 270000, Vietnam; phamhongquang@tnu.edu.vn \\ 4 High School for Gifted Students, Vinh University, Nghe An 460000, Vietnam; chungpx@vinhuni.edu.vn \\ 5 University of Social and Labour Affairs, Hanoi 100000, Vietnam; hungdv@ulsa.edu.vn \\ 6 Institute of Theoretical and Applied Research, Duy Tan University, Hanoi 100000, Vietnam; \\ nguyentientrung3@duytan.edu.vn \\ * Correspondence: duc@edlabasia.org; Tel.: +84-982-574-874
}

Received: 6 April 2020; Accepted: 19 May 2020; Published: 20 May 2020

\begin{abstract}
The overspread of the novel coronavirus-SARS-CoV-2-over the globe has caused significant damage to manufacturing and service businesses, regardless of whether they are commercial, public, or not-for-profit sectors. While both the short-term and long-term impacts of most companies can be approximately measured or estimated, it is challenging to address the enduring effects of COVID-19 on teaching and learning activities. The target of this research is to investigate students' manners of studying at home during the school suspension time as a result of COVID-19. Through analyzing original survey data from 420 K6-12 students in Hanoi, Vietnam, this work demonstrates the different learning habits of students with different socioeconomic statuses and occupational aspirations during the disease's outbreak. In particular, we featured the differences in students' learning behaviors between private schools and public schools, as well as between students who plan to follow STEM-related careers and those who intend to engage in social science-related careers. The empirical evidence of this study can be used for the consideration of the local government to increase the sustainability of coming policies and regulations to boost students' self-efficacy, as it will affect 1.4 million students in Hanoi, as well as the larger population of nearly 10 million Vietnamese students. These results can also be the foundation for future investigations on how to elevate students' learning habits toward Sustainable Development Goal 4 (SDG4) Quality Education-especially in fanciful situations in which the regular school operation has been disrupted, counting with limited observation and support from teachers and parents.
\end{abstract}

Keywords: sustainable education; learning habit; school closure; socioeconomic; occupational aspiration; COVID-19; SDG4; Vietnam; secondary school 


\section{Introduction}

Developing digital competency for the younger generation is always a primary concern of most governments toward Quality Education (Sustainable Development Goal 4) [1]. Educational digital transformation is not a technological renovation, but also a transition between generations. In particular, millennial teachers are taking over baby-boomer teachers, and the new generation of students are "born digital." Especially in countries that consider technology absorption as a vital sustainable development strategy, educating digital citizens is an essential pillar of the national education strategy [2]. Therefore, standing on the perspective of SDG4, educators should emphasize digital self-efficacy rather than the regular concept of self-efficacy. At a micro-level, teachers' teaching habits and learners' learning habits play essential roles in the transformation processes of any educational institution [3]. Romero-Rodríguez et al. [4] underlined the necessity of learners' selfefficacy and self-regulation toward sustainable academic achievement, especially in e-learning contexts. Concerning students' self-efficacy as a grand puzzle for their sustainable learning trajectory, several studies have been taken to examine Vietnamese students' learning habits. Le et al. [2] measured the ICT competencies of Vietnamese students regarding cognitive and non-cognitive skills among various social strata and figured out that even in big cities like Hanoi or Danang, students' level of e-device usage is not high. Moreover, Vuong et al. [5] provided a mosaic of Vietnamese students' reading habits and triggered further studies on examining students' self-efficacy amidst different social and cultural facets. Overall, the importance of self-regulated skills, such as ICT, noncognitive, and reading habits, need more attention from the government, school managers, teachers, and parents, especially in the urgent circumstances, such as the passive digital transformation due to COVID-19.

The success of students relies a lot on their prior knowledge, teacher and teaching quality, the possibility of accessing possibilities, socioeconomic status (SES), and their effort [6]. Students' learning habits are caused by and contribute to the students' intrinsic motivation [7]. However, students do not maintain the same learning habits during the summer, winter, and spring breaks as they do during school. Warner et al. [8] pointed out the significant changes in student learning and sleeping habits during holidays, in which the solid learning hours of school and homework are not maintained regularly. Notably, students' learning habits are partially distracted by the usage of social networks and entertainment activities at home [9] or suspended by traveling [10]. Notwithstanding, these kinds of degradation effects on learning habits are seasonal and predictable [8]. There is a limited number of studies regarding students' studying at home behavior during sudden school termination, in which the students are required to stay at home and have to adjust their living and learning habits $[11,12]$. Due to the pandemic, students also have to face potential mental issues, such as depression, fearfulness, worry, and stigmatization [7,8], which might also affect their learning habits. The longer that COVID-19 lasts, the higher quantity and level of issues and risks the educational system worldwide have to face.

During early January, 2020, the spreading of COVID-19 from Wuhan, China, alerted governments and societies worldwide [13]. Within a month, China locked down ten cities and closed all schools over the country [14], while neighboring countries had various perspectives and approaches toward the issue. Globally, nearly 300 million students were affected by school closure [15]. Countries such as Japan, Iran, Italy, and North Korea applied nationwide school shutdowns, while Vietnam, South Korea, Singapore, Thailand, France, Germany, and the United States adopted a localized school closure policy [16]. Regardless of the size of the pandemic and the debates on school closure policy, pedagogical transformation became a popular topic in most countries [17]. In a short time, various kinds of initiatives to support students and teachers have been released. For instance, top-tier universities, such as Harvard University [18] and Cambridge University [19], delivered guidelines and handbooks to support distance learning. Furthermore, various NGOs (NonGovernment Organizations) and NPOs (Non-Profit Organization) provided support and instructions to enhance mental health [20-22]. Ed-tech companies and publishing houses also introduced entirely free or occasionally free accounts and materials from their portfolios and databases [23,24]. 
This study acknowledges the encouragement of conducting novel research to minimize and prevent the potential effects of SARS-CoV-2, the cause of COVID-19 [23]. Vietnam has managed the infection rate of SARS-CoV-2 despite its limited resources and crowded population [25]. During early February, the country witnessed a controversial topic of closing schools nationwide or not after one extension week of the lunar new year due to COVID-19. Instead of closing schools until 9 February, all schools in over 63 provinces extended the suspension to 16 February, while detailed regulation about online teaching and learning had not yet been released [26]. On 14 February, the Ministry of Health suggested that local departments of education should consider the possibilities of stopping school suspension based on each province's particular situation [27]. After that, on 9 March, several provinces announced one or two additional weeks of school suspension [28]. In Vietnam, the concept of learning is often referred to as learning at school. Regarding this chaotic situation, either the school and teacher or the student and parent were confused about what they should do to ensure students' health and learning quality at the same time. Constructing proper self-learning habits also means consolidating the foundation of life-long learning and individual personality development [29]. The concern of educational quality and students' mental health is not limited to these closure weeks but also extends to this academic year, as well as its effects on the following years [30]. Thus, this research enriches the prior studies on students' learning behaviors during the sudden suspension of school, with empirical evidence from a developing country: Vietnam [31]. Furthermore, the findings of this paper contribute to minimizing the long-term side effects of COVID-19, fostering sustainable education within and beyond school, as well as enhancing capabilities when reacting to similar chaotic situations in the future.

\section{Theoretical Background}

\subsection{Students' Learning Habits}

The notion of study habits has been attracting attention from educational researchers for its influence on academic performance for a long time. It is usually discussed with study skills and study attitude, as Crede and Kuncel [32] put all three concepts together into the SHSA (Study habits, skills, and attitudes) construct, or regarded as comprising study skills and attitude in its theory [33]. The definition of study habits in literature can be summarized as consisting of two main features: (i) carefully planned study behaviors, such as note-taking, reviewing learning material, reading, consulting teachers, and arranging a suitable learning space, and (ii) the engagement in study sessions using the mentioned study behaviors [34,35].

Most studies on this topic are devoted to exploring its influence on academic achievement. Most research suggests that learning habits have a positive interrelationship with learning performance [36,37], while some found no relationship [32,38,39]. Nonis and Hudson [40] argue that the nature of this relationship is complicated, and what is considered a good habit is different depending on the situation. The impacts of study habits on test anxiety are matters of concern, with a predominant result of a negative relationship between these two concepts [41]. Although its consequences are discussed quite a lot, few studies focus on factors that influence study habits, and gender difference is the most found factor $[35,38]$.

Time spent studying is a critical component of study habits [34,40]. While time spent studying at school is controlled according to the school's schedule, studying at home is much more unsystematic and is affected by a lot of different factors. The findings on time spent studying at home can be found mostly on the topic of doing homework. However, the concept of doing homework does not cover the time that students spend studying with something other than what the teachers have given out. Wagner et al. [42] pointed out that learning at home includes many types of activities to elevate the overall academic performance, in which homework is just one type of learning, and is limited to the assigned tasks from teachers only. Especially when schools everywhere have to close due to the attack of COVID-19, students have to stay at home, adjust their study habits, and deal with technological challenges at the same time, so studying at home is not all about doing homework anymore. Lacking understanding of this phenomenon will lead to failures in educational policy and 
practices, which will cause enormous and long-lasting costs to society [43]. Nonetheless, studies exploring the concept of "working at home for school" are rare despite its importance, and there is no study that investigates the time spent studying during disruptive times, as mentioned before. The relationship between students' time spent on homework or studying at home and learning results are still being debated. While some scholars found a positive relationship indicating the more time students invest, the better the achievement [44], some found no correlation and argue that time spent on studying only matters when the quality of the study time is taken into consideration [45]. Factors that influence the time spent studying at home are gender differences [42,44], motivation [46], academic interest, school anxiety, and parental pressure [47]. The time spent studying at home is an even more critical matter in Vietnam, as Larson and Verma [48] found a gap in the time spent on schoolwork outside school between East Asian and U.S students, especially in adolescents, in which East Asian adolescents spend substantially more time on academic activity than U.S adolescents.

\subsection{Socioeconomic Status and Learning Habits}

Le et al. [31] stated the correlation between SES and students' reading habits and their influence on academic achievement. SES is incorporated by characterizing variables, such as student ages [49], parental education, parental occupational prestige, family income [50,51], and home resources [52] [53]. Ensminger et al. [54] concluded that three indicators of SES-education, occupation, and income-are positively correlated.

Besides contributing to the overall SES, each of these components represents a substantially separated aspect of SES based on different empirical studies [55,56]. Blanden and Gregg [57] stated that family income and children's education were relevant and strengthened through time, and they also found that "income does have a causal impact on educational outcomes." In addition, parental education was one of the most critical SES elements, as it impacts students from childhood to adolescence and even further [58,59]. In individualistic societies, such as the USA and UK, parental education correlates with parent's income and [60-62] stated that the insights of particular social strata's prestige and culture could be reflected through parental occupation. Therefore, Hauser [51] considered parental occupation more important than parental education and income, regarding the weight of these variables toward the overall SES. Furthermore, home resources, such as books, computers, a study room, the availability of Internet [63,64], accessibility of extra educational services $[65,66]$, and a positive home learning environment [67] are essential antecedents to students' success.

SES had significant indirect effects on the learning habits of children through parental involvement [68]. In general education [69] as well as special education [70], parental involvement strongly affects student learning activities and outcomes. McNeal [71] mentioned that parental involvement has more notable effects on behavioral issues than children's cognitive outcomes. The higher participation of parents in school activities was observed from families with higher SES [72]. Furthermore, they could provide their children with more exceptional support through discussions and involvements [71] or proper supporting resources and learning conditions [73]. According to a longitudinal research of 10 years by Carter [74], parental support enhances the academic performance of both primary, lower, and upper secondary students. Researchers noticed the compelling impact of family involvement over students' learning results [75]. Besides academic achievement, parental involvement also impacts other aspects, such as social and emotional factors. As a consequence, they create a wide range of issues and support at the same time [76]. For instance, on the one hand, a parent's over-expectation could lead to their control over the student's learning activities and outcomes [77,78]. On the other hand, their step-by-step help also encourages children to accomplish school assignments and improve students' attendance $[79,80]$.

Last but not least, parental involvement also affects children's cognitive competences and learning motivation [81-83]. The more that parents valued their children's learning process and achievement, the stronger motivation and competence their children perceived [84]. Researchers proved that because of their social prestige, parents might influence the child's behavior and attitude toward homework [85,86]. Researchers also found that even at home or in school, parental involvement was affiliated positively with the student's motivation [87]. In particular, the higher 
levels of education the parents have, the more stimulating the home environment they provide for their children to promote their cognitive development [88].

\subsection{Occupation Aspirations}

Occupational aspiration presents students' orientation and yearning toward their target career [89]. Adolescent vocational orientations are affected by many contributory factors, one of which comes from gender roles instead of gender. Dweck and Elliot [89] examined the relationship between occupational orientation and gender throughout two kinds of goal orientations (mastery and performance-approach). They found no association between gender and these kinds of orientation. Nevertheless, there are some studies measuring goal orientations, but the results were around gender-related issues. Anderman and Young [90] realized that boys preferred performance-approach goals more than girls, and girls favored more mastery goals than boys. Consistent with these researchers, Middleton and Midgley [91] fostered gender inclusiveness in each goal orientation by putting it in academic settings, and found that mastery-oriented girls displayed a more efficacious tendency in learning, such as high self-regulation learning and a higher engagement in studying than performance-oriented boys. Although these findings sounded reasonable, Hutchins [92] continued to support Dweck and Elliot [89], stating that the significant relationships between both femininity, masculinity, and performance-approach still exist. Furthermore, both Makarova et al. [93] and Vuong et al. [94] adopted this standpoint. They stated that STEM-related school subjects were believed to follow a male domain due to their preference for STEM-related jobs. Thus, regarding both learning and working purposes, classifying the appropriate behaviors and characteristics of subject or career for each gender is considered apparent, especially for students from collectivist cultures, who are more influenced by their parents.

Another additional factor in children's career aspirations is parents' involvement. Bejanyan et al. [95] stated that parents from collectivist backgrounds rarely forgot to put their passions into their children. That explains adolescents' loss of interest in learning because of parents' pressure to follow their wishes. Nevertheless, many are still satisfied with their parents' arrangement [96]. Garcia et al. [97] found the moderating effect of adolescent-parent relationships over learning outcomes and selfefficacy. Specifically, the higher the self-efficacy, the better the learning outcomes. Moreover, Sawitri and Creed [98] presumed that being compatible with parents' orientation might never be a dead-end road when their parents smooth their career aspirations by the frequent encouragement and unceasing concern. Simultaneously, when both adolescents and parents maintain sustainable compatibility, a crisis of confidence of these adolescents decreases during career-related tasks. However, all of these results have supported some good points from the congruence without validating its direct impact on learning habits at home.

\section{Research Approach}

\subsection{Research Questions}

The aspiration of this study was not to construct a new framework to measure students' learning habits, as well as learning effectiveness, which needs longitudinal observations. Regarding the urgent changes in the educational delivery method, this paper aimed to examine the differences in students' studying habits during school suspension time as a result of COVID-19 and its mediating factors. The following research problems were addressed:

1. Are there differences in students' learning habits during sudden school closure among different socioeconomic status?

2. Are there differences in students' learning habits during sudden school closure among different occupational aspirations?

3. How does the student's perception about self-learning and other factors influence students' learning habits during sudden school closure time? 


\subsection{Sampling Method}

As Vietnam's political and cultural center, Hanoi has 1556 schools with more than 1.4 million Pre-K to 12 students, which is 17.5 percent of the city's total population [99]. During the sudden school suspension, it was impossible to provide proper observation and support to this considerable number of students. Thus, this study chose Hanoi as the site to examine the readiness and effectiveness of a typical major city of Vietnam, in which most students from all areas have proper access to the Internet.

We contacted several public and private schools to collect the data, but they were unable to manage the data collection and were unable to provide students' phone numbers. To secure the timely response to the issue, we spread the questionnaires through a network of lower secondary and upper secondary teachers and parents in various educational forums on Facebook. The snowball sampling approach was adopted from 7 February, 2020 to 28 February, 2020: the first two weeks of school closure due to COVID-19 in Vietnam. Parents and teachers were asked to validate their students' ability and willingness to participate in the survey before forwarding the survey to students. Students were required to read and confirm the consent form before moving to the detailed questions. The data collection protocol was observed and approved by the Institutional Review Board of EdLab Asia Educational Research and Development Center, approval No 200214. We tested the results of 50 early respondents by factor loadings before continuing the survey spread, in which a total of 460 responses were received. We excluded participants who had invalid answers (such as their year of birth was after 2009, which meant they were primary students; or learning hours were more than $20 \mathrm{~h}$ per day, which seemed to be the learning hours per week, but we had no evidence to convert it into learning hours per day). As a result, we analyzed a dataset of 420 valid observations.

\subsection{Research Design}

This research article aimed to have an overview of the learning habits of students during school suspension because of the COVID-19 pandemic and find relationships among SES, career orientation, and students' learning habits. In the questionnaire, students were asked questions related to three major categories: (i) students' demographics [50,51,54]; (ii) students' habits of study at home during COVID-19 [34,35]; and (iii) students' self-report on their academic competencies, necessities [71], and effectiveness during the pandemic. In addition, an additional question was added to examine how teachers elevated their lessons beyond regular academic content. Students were asked whether they learned extended knowledge of public health, sustainable environmental development, and sustainable social development during these distance classes or not.

The full dataset of 460 observations was cleaned and resulted in a dataset of 420 valid observations for data analysis. The new dataset was saved in the xlsx format for formal analysis in $\mathrm{R}$ and published in Mendeley's data repository for further interpretation [100]. The primary methods used were descriptive statistics, ANOVA analysis, and ordinary least squares (OLS) regression, which are explained in the next part.

The influences of SES and career orientation over learning habits were examined by linear regression-specifically, when we used the learning hours during COVID-19 (hr_covid) as the dependent variable. The regression model (1) included gender, grade levels, and the number of siblings as independent variables. The regression model (2) examined the moderating effect of family income and school type, and model (3) highlighted the differences of students with different occupational aspirations, based on university entrance exam subject groups.

$$
\begin{gathered}
\text { Hr_covid } \sim \beta 0+\beta 1{ }^{*} \text { gender }+\beta 2{ }^{*} \text { grade }+\beta 3{ }^{*} \text { sib }+u \\
\text { Hr_covid } \sim \beta 0+\beta 1{ }^{*} \text { income }+\beta 2{ }^{*} \text { school_type }+\mathrm{u} \\
\text { Hr_covid } \sim \beta 0+\beta 1{ }^{*} \text { exam }+\mathrm{u}
\end{gathered}
$$

\section{Results}

The students' learning hours during COVID-19 based on demographics are presented in Table 1. On average, the surveyed students spent around $2.8 \mathrm{~h}(\mathrm{SD}=1.60)$ studying at home on a typical 
day, and about $3.7 \mathrm{~h}(\mathrm{SD}=2.64)$ studying on days of school closure due to the COVID-19 pandemic. These numbers were at a middle level when compared with the average time spent on homework per day in other Asian countries, such as Japan $(2.2 \mathrm{~h}$ for junior high and $2.5 \mathrm{~h}$ for high school students), Korea ( $3 \mathrm{~h}$ for high schoolers), Taiwan ( $3.7 \mathrm{~h}$ for 11 th graders), and India ( $4-5 \mathrm{~h}$ for high school students) [48]. However, in the future, there will likely be a higher number of learning hours, since the collected data was only from the first two weeks of school closure. After that, the Vietnam Ministry of Education and Training published Official dispatch 793/BGDĐT-GDTrH about enhancing teaching on the Internet and television during the time of preventing and fighting against COVID-19 [101]. As a result, compulsory study time for students, as well as their self-learning hours, increased.

Table 1 illustrates the demographic of respondents associated with learning hours during COVID-19 using a descriptive analysis. As can be seen, more than half of the surveyed students used less than $4 \mathrm{~h}$ to study. Regarding school type, $75 \%$ of international school students used less than $4 \mathrm{~h}$ for learning, $25 \%$ of them used more than $7 \mathrm{~h}$ to study, while the numbers in private school were $47.9 \%$ and $10.6 \%$, respectively. Regarding self-evaluation about learning competency and English competency, it was clear that students who evaluated as "below average" or "average" would spend less time to study (more than $60 \%$ of them studied for less than $4 \mathrm{~h}$ ) than those who thought they were "good" and "excellent."

Table 1. Demographic of respondents associated with learning hours during COVID-19.

\begin{tabular}{|c|c|c|c|c|c|c|}
\hline & \multicolumn{2}{|c|}{ Under $4 \mathrm{~h}$} & \multicolumn{2}{|c|}{ From 4 to $7 \mathrm{~h}$} & \multicolumn{2}{|c|}{ Over $7 \mathrm{~h}$} \\
\hline & Frequency & Percent & Frequency & Percent & Frequency & Percent \\
\hline \multicolumn{7}{|c|}{ Gender } \\
\hline Male & 91 & $54.8 \%$ & 55 & $33.1 \%$ & 20 & $12.0 \%$ \\
\hline Female & 129 & $54.0 \%$ & 80 & $33.5 \%$ & 30 & $12.6 \%$ \\
\hline Not public & 9 & $60.0 \%$ & 5 & $33.3 \%$ & 1 & $6.7 \%$ \\
\hline \multicolumn{7}{|c|}{ Grade level } \\
\hline Secondary school & 119 & $50.9 \%$ & 88 & $37.6 \%$ & 27 & $11.5 \%$ \\
\hline High school & 110 & $59.1 \%$ & 52 & $28.0 \%$ & 24 & $12.9 \%$ \\
\hline \multicolumn{7}{|c|}{ School type } \\
\hline (i) Public school (normal) & 111 & $59.7 \%$ & 57 & $30.6 \%$ & 18 & $9.7 \%$ \\
\hline (ii) Public school (Gifted) & 67 & $50.8 \%$ & 44 & $33.3 \%$ & 21 & $15.9 \%$ \\
\hline (iii) Private school (normal) & 45 & $47.9 \%$ & 39 & $41.5 \%$ & 10 & $10.6 \%$ \\
\hline (iv) International school & 6 & $75.0 \%$ & 0 & $0.0 \%$ & 2 & $25.0 \%$ \\
\hline \multicolumn{7}{|c|}{ Father's job } \\
\hline STEM-related & 74 & $52.5 \%$ & 51 & $36.2 \%$ & 16 & $11.3 \%$ \\
\hline Social Sciences-related & 87 & $50.6 \%$ & 60 & $34.9 \%$ & 25 & $14.5 \%$ \\
\hline Free & 45 & $61.6 \%$ & 19 & $26.0 \%$ & 9 & $12.3 \%$ \\
\hline Others & 23 & $67.6 \%$ & 10 & $29.4 \%$ & 1 & $2.9 \%$ \\
\hline \multicolumn{7}{|c|}{ Mother's job } \\
\hline STEM-related & 17 & $53.1 \%$ & 11 & $34.4 \%$ & 4 & $12.5 \%$ \\
\hline Social Sciences-related & 140 & $51.9 \%$ & 93 & $34.4 \%$ & 37 & $13.7 \%$ \\
\hline Free & 42 & $66.7 \%$ & 15 & $23.8 \%$ & 6 & $9.5 \%$ \\
\hline Others & 30 & $54.5 \%$ & 21 & $38.2 \%$ & 4 & $7.3 \%$ \\
\hline \multicolumn{7}{|c|}{$\begin{array}{l}\text { University entrance exam's subject group } \\
\end{array}$} \\
\hline A (Math, Physics, Chemistry) & 31 & $59.6 \%$ & 17 & $32.7 \%$ & 4 & $7.7 \%$ \\
\hline A1 (Math, Physics, English) & 20 & $31.3 \%$ & 34 & $53.1 \%$ & 10 & $15.6 \%$ \\
\hline B (Math, Biology, Chemistry) & 8 & $34.8 \%$ & 14 & $60.9 \%$ & 1 & $4.3 \%$ \\
\hline $\begin{array}{c}\text { C (Literature, History, } \\
\text { Geography) }\end{array}$ & 16 & $72.7 \%$ & 3 & $13.6 \%$ & 3 & $13.6 \%$ \\
\hline $\begin{array}{l}\text { D (Literature, Foreign } \\
\text { Language, Math) }\end{array}$ & 111 & $59.4 \%$ & 50 & $26.7 \%$ & 26 & $13.9 \%$ \\
\hline Other & 43 & $59.7 \%$ & 22 & $30.6 \%$ & 7 & $9.7 \%$ \\
\hline \multicolumn{7}{|c|}{ Family monthly income (USD) } \\
\hline (i) Under 430 & 36 & $58.1 \%$ & 20 & $32.3 \%$ & 6 & $9.7 \%$ \\
\hline
\end{tabular}




\begin{tabular}{ccccccc} 
(ii) From 430 to under 860 & 84 & $59.6 \%$ & 47 & $33.3 \%$ & 10 & $7.1 \%$ \\
(iii) From 860 to under 1290 & 54 & $55.7 \%$ & 28 & $28.9 \%$ & 15 & $15.5 \%$ \\
(iv) From 1290 to under 1720 & 18 & $36.0 \%$ & 24 & $48.0 \%$ & 8 & $16.0 \%$ \\
(v) From 1720 to under 2,150 & 15 & $50.0 \%$ & 9 & $30.0 \%$ & 6 & $20.0 \%$ \\
(vi) More than 2150 & 22 & $55.0 \%$ & 12 & $30.0 \%$ & 6 & $15.0 \%$ \\
\hline \multicolumn{7}{c}{ Self-evaluation on learning capability } \\
Below Average & 6 & $85.7 \%$ & 1 & $14.3 \%$ & 0 & $0.0 \%$ \\
Average & 70 & $64.2 \%$ & 33 & $30.3 \%$ & 6 & $5.5 \%$ \\
Good & 128 & $51.0 \%$ & 91 & $36.3 \%$ & 32 & $12.7 \%$ \\
Excellence & 25 & $47.2 \%$ & 15 & $28.3 \%$ & 13 & $24.5 \%$ \\
\hline Below Average & Self-evaluation on English capability & & & \\
Average & 23 & $65.7 \%$ & 9 & $25.7 \%$ & 3 & $8.6 \%$ \\
Good & 82 & $60.7 \%$ & 44 & $32.6 \%$ & 9 & $6.7 \%$ \\
Excellence & 99 & $51.8 \%$ & 65 & $34.0 \%$ & 27 & $14.1 \%$ \\
& 25 & $42.4 \%$ & 22 & $37.3 \%$ & 12 & $20.3 \%$ \\
\hline
\end{tabular}

Regarding the ANOVA analysis, the test of homogeneity (Appendix A) classified that six variables (gender; grade level; school type; mother's job; university entrance exam's subject group; and monthly income) had significance levels bigger than 0.05 . Thus, these variables were eligible for an ANOVA analysis (Appendix B). On the other hand, the other three (father's job; self-evaluation on learning capability; self-evaluation on English capability) were adopted for the Robust Test of Equality of Means (Appendix C). The results reported that there were only four factors associated with the differences in students' learning habits: university entrance exam's subject group; selfevaluation on learning capability; and self-evaluation on English capability.

Figure 1 reported that students who maintained their learning because of their intrinsic motivation to ensure regular academic progress and to sustain their learning habit (they answered "agree" or "strongly agree" for the question) tended to learn for more extended hours (1.68 and 1.86 $\mathrm{h}$ on average). Meanwhile, students who studied because they were influenced by other people (extrinsic motivation) tended to learn for fewer hours. Those who were not affected by other people spent more time studying (on average from 1.77 to $1.83 \mathrm{~h}$ ).

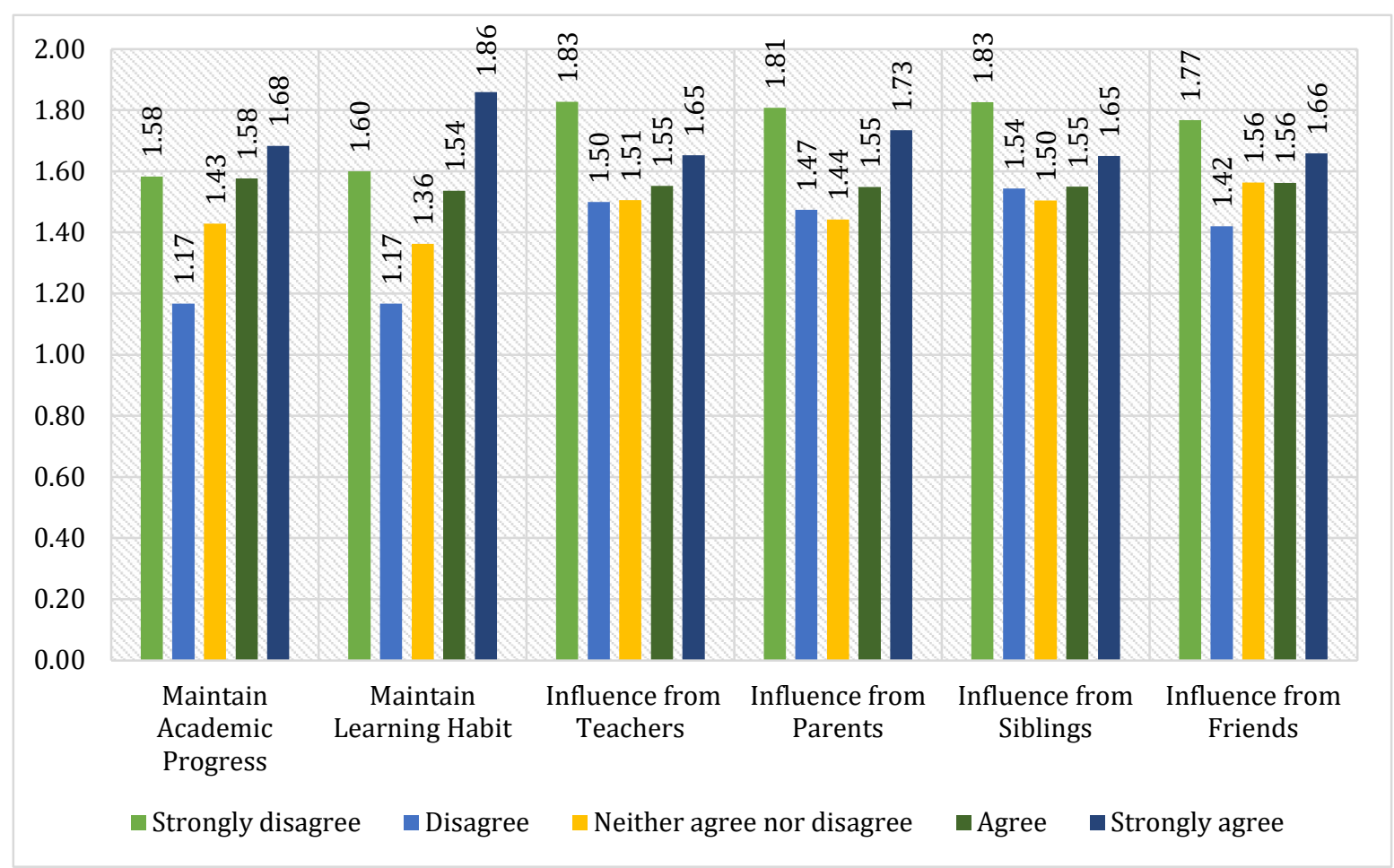

Figure 1. Students' perception of the necessity of self-learning associated with learning hours during COVID-19. 
Figure 2 illustrates the factors that affected students' learning effectiveness based on their selfevaluation associated with their learning hours. According to the students' view, the effectiveness of self-learning, when achieved because of adequate support from family, a comfortable learning environment, sufficient learning resources, or communication with friends, would lead to fewer learning hours (on average from 1.88 to $1.98 \mathrm{~h}$ ). Those were considered extrinsic factors, in contrast to three intrinsic factors: learning motivation, ability to set daily learning objectives, and concentration skill, which were associated with more learning hours (on average from 2.02 to $2.09 \mathrm{~h}$ ).

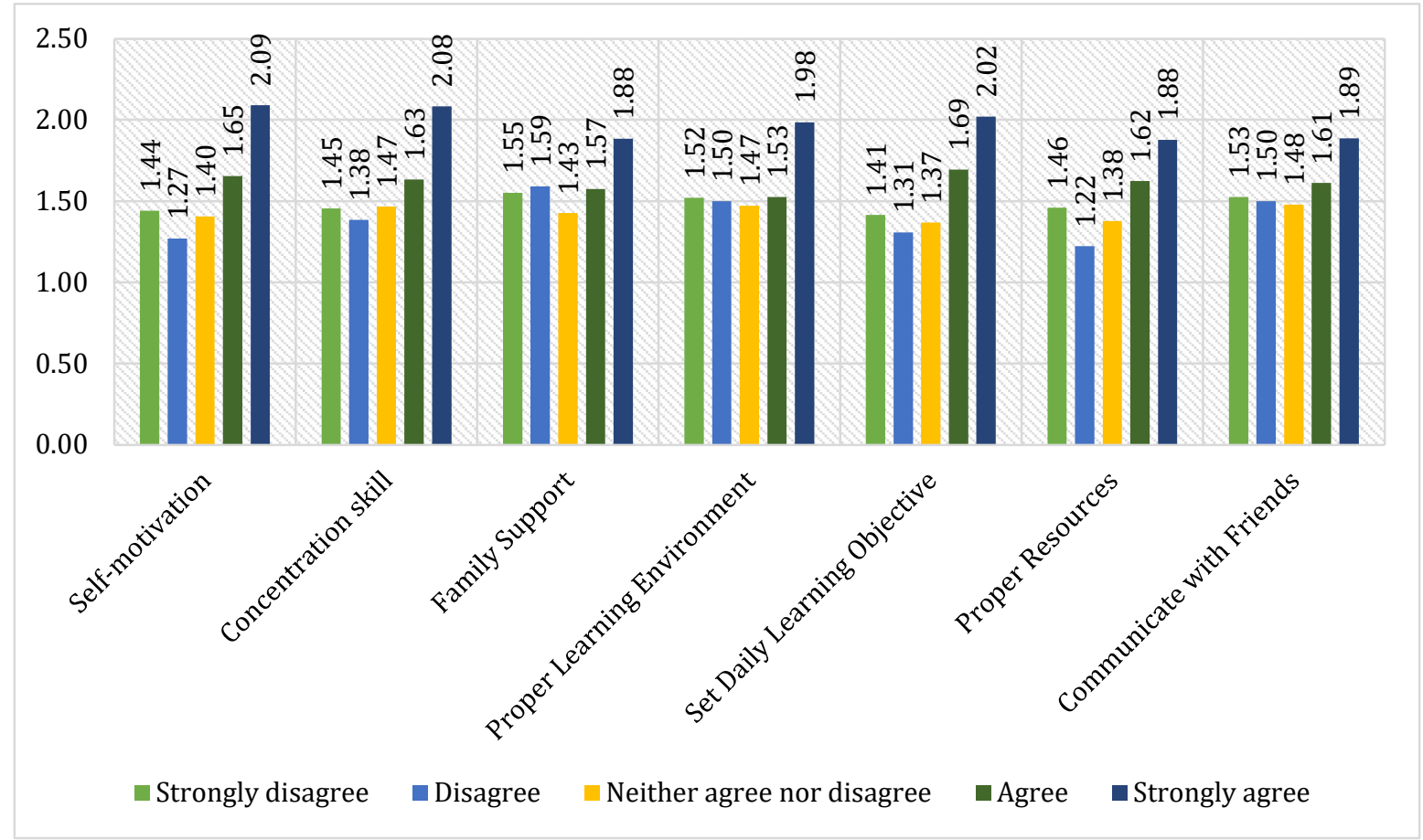

Figure 2. Factors that support students' effective learning associated with learning hours during COVID-19.

To supplement the results of the ANOVA analysis, Table 2 reports significant differences in students' learning habits regarding their school types, grade levels, and occupational aspiration. In particular, students from private schools spent more time learning during COVID-19 than students from public schools. Older students tended to spend fewer hours learning online or learning with instruction.

Table 2. Ordinary least squares (OLS) regression of socioeconomic status and career orientation on learning hours.

\begin{tabular}{|c|c|c|c|c|c|}
\hline & & Hr_covid & Online & Offline & $\begin{array}{c}\text { With } \\
\text { Instruction }\end{array}$ \\
\hline \multirow{5}{*}{$\begin{array}{l}\text { Socioeconomic } \\
\text { status }\end{array}$} & Gender & & & & \\
\hline & Grade level & & $\begin{array}{l}-0.4495^{* *} \\
R 2=0.2476\end{array}$ & & $\begin{array}{l}-0.4704^{* * *} \\
R 2=0.5953\end{array}$ \\
\hline & Siblings & & & & \\
\hline & Income & & & $\begin{array}{c}-1.5929 *(\mathrm{iii}) \\
\mathrm{R} 2=0.2222\end{array}$ & \\
\hline & School type & & $\begin{array}{l}2.0101^{* *}(\mathrm{iii}) \\
\mathrm{R} 2=0.2385\end{array}$ & $\begin{array}{l}1.4711 *(\mathrm{iii}) \\
\mathrm{R} 2=0.2222\end{array}$ & $\begin{array}{c}1.8327^{* * *}(\mathrm{iii}) \\
\mathrm{R} 2=0.6300\end{array}$ \\
\hline $\begin{array}{c}\text { Occupational } \\
\text { aspiration }\end{array}$ & Exam & $\begin{array}{c}1.2554 *(\mathrm{~A} 1) \\
\mathrm{R} 2=0.3947\end{array}$ & $\begin{array}{c}-2.2891^{*}(\mathrm{D}) \\
-2.0715^{*} \\
\text { (Other) }\end{array}$ & & $\begin{array}{c}-1.5765^{*}(\mathrm{~A} 1) \\
-1.7400^{* *}(\mathrm{D}) \\
\mathrm{R} 2=0.2749\end{array}$ \\
\hline
\end{tabular}




\section{$\mathrm{R} 2=0.1856$}

${ }^{*}$ Correlation is significant at the 0.05 level; ${ }^{* *}$ correlation is significant at the 0.01 level; ${ }^{* * *}$ correlation is significant at the 0.001 level; (iii) school type is private school; (iii) income belongs to group from 860 to under 1290 USD; university entrance exam's subject groups: A1 (mathematics, physics, English), D (literature, foreign language, mathematics), Other (university entrance exam's subject group other than A, A1, B, C, D).

Figure 3 visualizes the additional know-how on several sustainable topics, which students were taught in the distance-learning lesson during COVID-19. The topics were related to knowledge about preventive health care, SARS-Cov-2, environmental sustainable development, societal sustainable development, and E-learning tools. It is clear that students learned a lot about preventive health care and SARS-CoV-2, with more than 70\% of students responding "agree" and "strongly agree." The number for sustainable development knowledge was around 50\%. Moreover, students did not seem to learn much about e-learning tools. Since these were the first weeks of the school closure, both schools and students had not found or become familiar with many online tools to facilitate their learning.

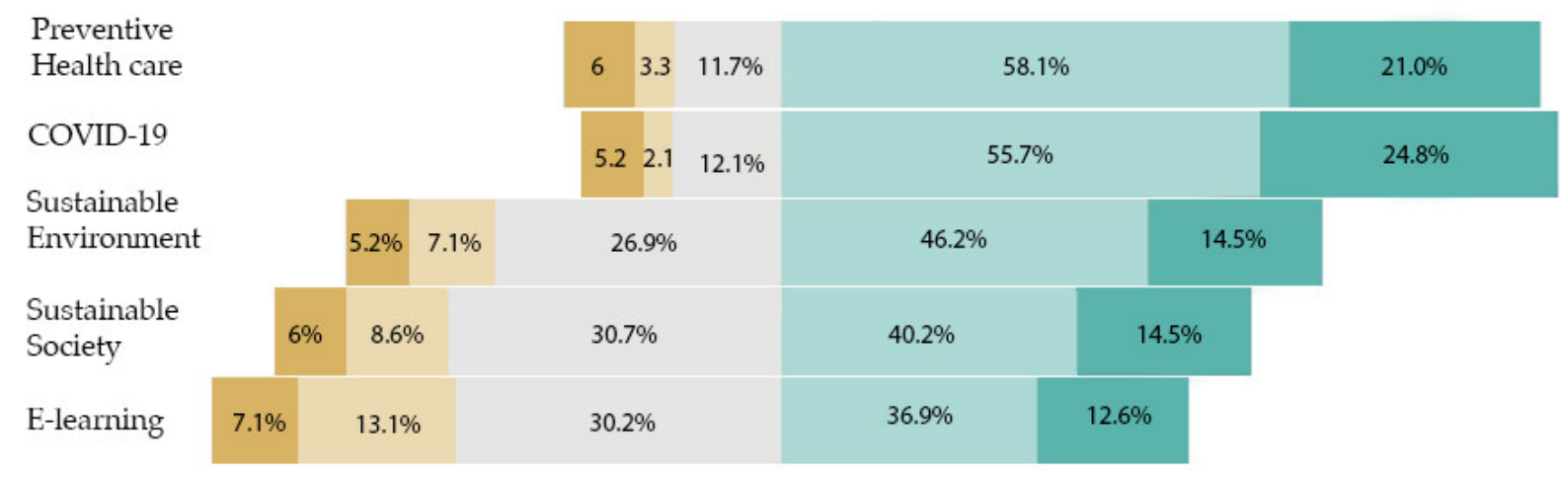

$\square$ Strongly disagree $\square$ Disagree $\quad$ Neither agree nor disagree $\square$ Agree $\square$ Strongly agree

Figure 3. Extended know-how on several sustainability topics during COVID-19's online classes.

\section{Discussion}

Sustainable education is not a status quo, but an incremental process, in which the learner's selfefficacy always plays a crucial role [5]. As novel evidence about Vietnamese K6-12 students' learning at home habits during school closure due to COVID-19, the findings of this study can help to tackle the potential issues of such sudden situations in the future. Notably, this research found significant differences in students' learning routines from different school types, grades, and career orientations. Furthermore, there were notable differences in learning habits among students with varying learning capabilities, motivation, and self-regulation.

Regarding the first research question, the regression results stated that students in private schools spent more hours ( $4.0 \mathrm{~h}$ compared to $3.4 \mathrm{~h}$ on average) on learning during the pandemic than students in public schools. This result was consistent with that of Ali et al. [68], who concluded that the studying at home hours of students from private schools was higher than that of public school students. Moreover, students who studied in private schools received support from parents more than their peers in public schools [68]. In our study, students in private schools spent more hours on both online learning, offline learning, and learning with instruction than those of students in public schools. This result can be combined with other findings, such as students' study concentration or inclination to study for the exam, to produce conclusions about students' learning habits in private schools and public schools.

Secondly, older students tended to spend fewer hours learning online (on average, $2.5 \mathrm{~h}$ compared to $2.9 \mathrm{~h}$ of the younger group) or learning with instruction (on average $1.1 \mathrm{~h}$ compared to $1.5 \mathrm{~h}$ of the younger group). This result was contrary to what was found in the research of Ke and 
Kwak [49], in which older students spent more time on online learning activities. In our sample, it is understandable that older students did not need as much instruction as younger students. Thus, the learning hours with instruction decreased as age increased. Regarding online learning, Oyemi et al. [9] claimed that students' learning habits are partially distracted by the usage of social networks and entertainment activities at home. Specifically, senior students consume more hours of entertainment on the Internet than students at lower grade levels $[60,61]$. As a result, it is apprehensible that students in higher grade levels would allocate less time for online learning, given their distractions, even though they might spend more time using the Internet.

A valuable insight is that we found no difference in learning habits between genders, which contrasted with previous empirical studies that found that female students spend more time studying at home than their male friends [40,41]. Students' learning habits are influenced the most by their parents and teachers. However, family income only had partial influence over students' learning habits, and the only meaningful result recorded belonged to the over-average income group (between 860-1920 USD per month). Students from these families spent less time learning offline during sudden school closure than the other groups. An explanation for this is that high-income families would have plenty of home resources, more internet access, a premium subscription to online courses, and more online learning and less offline learning. Some studies suggested similar results, in which home resources, such as abundant learning materials, a convenient learning space, and accessibility of additional opportunities and services, can affect students' academic performance $[64,98]$. Thus, the moderating effect from parents over students' learning habits might be caused by sociocultural factors rather than socioeconomic factors. Finally, students' siblings had no significant influence on students' learning habits.

Regarding research question two, there were differences in students' learning habits during the sudden school closure among different occupational aspirations, mainly in group A1 (math, physics, chemistry) and group D (literature, foreign language, math). Students who planned to take exams with group A1 tended to study more hours on average $(1.2 \mathrm{~h})$ and preferred to study with less instruction from other people. Students who planned to take exams with group D also tended to spend more hours of self-learning but did not prefer online learning, with an average of $2 \mathrm{~h}$ less than other groups. Self-efficacy is people's judgment about, and the ability to, control their competencies across various circumstances [102,103]. In academic settings, Bassi et al. [104] found that students who reported higher self-efficacy spent more time solving home assignments. In contrast, students with lower levels of self-efficacy tended to avoid schoolwork and replaced it with leisure activities. In this study, we did not measure students' self-efficacy, yet there were two questions related to one efficacy factor-namely, students' belief in their learning ability regarding a particular subject [103]. We found that students who reported having high self-learning competency would spend more time (about $30 \mathrm{~min}$ more) studying during school closure than those who reported lower self-learning competency.

Regarding the final research question, we found several differences in students' learning habits based on their motivation to learn and their self-regulation. Respecting learners' intrinsic motivation, students who thought that self-learning was necessary because it maintained their learning habits spent about $40 \mathrm{~min}$ more studying during school closure. Meanwhile, extrinsic motivation, such as influences from parents, teachers, siblings, or friends, did not have notable effects on students' learning hours. Among these influencers, students who learned because of their siblings' affection spent about $20 \mathrm{~min}$ less to study. These findings were partly consistent with what was found by Bergin [46]: that intrinsic motivation is the reason children do homework, not extrinsic motivation. According to Schunk [105], self-regulated learning is the discipline that can be triggered by students' perceptions and behaviors toward learning objectives. In our research, students who explained their self-learning effectiveness by being self-motivated and setting proper learning outcomes for each day often studied 20 to 30 min more.

Besides, students with various learning resources spent more time studying than those with more scattered resources. Some studies suggested similar results, where the availability and diversity 
of learning material, equipment, and extended educational opportunities could affect students' academic performance [64,98].

Last but not least, the empirical evidence stated that Vietnamese teachers took advantage of the closure by integrating additional know-how into the online lesson properly. The data indicated that $80.5 \%$ and $79.1 \%$ of students accessed additional knowledge about SARS-CoV-2 and overall preventive healthcare, respectively. About $60.2 \%$ and $54.5 \%$ of the students reported that their lessons were elevated beyond the regular subject contents by the integration with sustainable environmental development and sustainable social development. This is a positive signal regarding the country's movement from content-based teaching into competency-based teaching.

\section{Conclusions}

Sustainable education development requires the involvement of various stakeholders toward the structure of the educational system, educational policies, and practices [106]. As an emerging country, Vietnam is dealing with multiple well-known and unknown struggles to pursue sustainable education [59]. Thus, the discoveries of this work have several implications in both the short-term and long-term. First, the study responded to the suggestion of Vuong et al. [5] to examine students' self-efficacy among different social strata. In particular, we investigated the influence of socioeconomic factors over Vietnamese students' learning habits during the fanciful situation of COVID-19. In detail, there were significant differences in students' learning habits among students from different types of schools and grade levels. Regarding the family income, the only difference belonged to students in families with above-average income (from 860 to under 1290 USD). Therefore, future policies and practices on distance learning should pay much attention to the characteristics of various school types and grade levels. Second, the learning habits of students with different levels of self-competencies, English, and career aspirations were clarified. Further investigations should focus on this area to figure out the mechanism behind this phenomena to optimize the learning habits of students with different capabilities. Moreover, students' perception of the necessity of self-learning during the pandemic revealed differences in their learning habits. Also, the supportiveness of factors that accelerated student learning and the teachers' efforts toward a sustainable education development goal was illustrated. Regarding all of these self-efficacy-related learning habits during the digital transformation process, policymakers, educational managers, and education practitioners need to reconsider the importance of the United Nations' Sustainable Development Goal 4: Quality Education.

Furthermore, several limitations can be tackled by future investigations. First, the survey was conducted within the first two weeks of the school closure period, in which the support from the school and social awareness about online learning was not as high as in the coming weeks. Thus, an additional investigation after the end of COVID-19 is necessary. Secondly, the survey was designed for the unique target of this study, which is timely; thus, the validity of the questionnaires was tested within the first 50 respondents only. Further survey constructs and validation should be considered in the future to examine students' online learning habits. Thirdly, the socio-demographics of this study's population fit with major cities only. When concerning other provinces and cities, in which access to the Internet is limited and the role of private schools is not significant, different perspectives and scales of socioeconomic measurement should be applied. Furthermore, the sample size was not big enough; thus, some subsets of variables were not balanced: for example, there were many respondents from high school but not from middle school, or too many students chose subject group $\mathrm{D}$ (literature, foreign language, mathematics) compared to other groups.

Author Contributions: T.T.: Conceptualization, Methodology A.-D.H.: Conceptualization, Methodology, Investigation, Writing-Review \& Editing Y.-C.N.: Investigation, Data Curation, Writing-Original Draft L.C.N.: Investigation, Writing-Original Draft N.-T.T.: Investigation, Writing-Original Draft Q.-H.P.: WritingReview \& Editing C.-X.P.: Writing-Review \& Editing Q.-A.L.: Investigation, Writing-Original Draft V.-H.D.: Data Curation T.-T.N.: Writing - Review \& Editing. All authors have read and agreed to the published version of the manuscript. 
Funding: This research was funded by National Foundation for Science and Technology Development, VietnamNAFOSTED (09/2015/TT-BKHCN).

Acknowledgments: The COVID-19 is causing unimaginable impacts on the educational system worldwide. Regarding the situation of Vietnam, a country always considers education as the top national priority. Vietnamese parents are always amenable to spend their savings or even willing to sell their houses to secure their children's learning. Even during the Vietnam war, the educational system has never been suspended as much as this time. Thus, we want to take advantage of this research as an encouragement for all Vietnamese educators, students, and parents, especially the teachers who have not had a salary for the last three/four months, and the school owners who are facing the risk of bankruptcy. We would like to say thanks to all students who participated in this study, as well as teachers and parents, who supported to ensure the ethical considerations and spread over the questionnaires. We also would like to acknowledge all doctors, medical staff, government officers, and volunteers who are fighting with COVID-19. Last but not least, we would like to express our gratitude to the editorial board and all reviewers who dedicated themselves to making the results of this work appear novel.

Conflicts of Interest: The authors declare no conflict of interest.

Appendix A. Test of Homogeneity of Variances

\begin{tabular}{ccccc}
\hline & Levene Statistic & df1 & df2 & Sig. \\
\hline Gender & 0.398 & 2 & 417 & 0.672 \\
\hline Grade level & 0.382 & 1 & 418 & 0.537 \\
\hline School type & 1.717 & 3 & 416 & 0.163 \\
\hline Father's job & 2.855 & 3 & 416 & 0.037 \\
\hline Mother's job & 1.338 & 3 & 416 & 0.261 \\
\hline University entrance exam's subject group & 2.004 & 5 & 414 & 0.077 \\
\hline Family monthly income (USD) & 1.982 & 5 & 414 & 0.080 \\
\hline Self-evaluation on learning capability & 8.842 & 3 & 416 & 0.000 \\
\hline Self-evaluation on English capability & 2.863 & 3 & 416 & 0.037 \\
\hline
\end{tabular}

\section{Appendix B. ANOVA Results}

\begin{tabular}{|c|c|c|c|c|c|c|}
\hline ANOVA & & $\begin{array}{l}\text { Sum of } \\
\text { Squares }\end{array}$ & df & $\begin{array}{c}\text { Mean } \\
\text { Square }\end{array}$ & $\mathbf{F}$ & Sig. \\
\hline \multirow{3}{*}{ Gender } & $\begin{array}{l}\text { Between } \\
\text { Groups }\end{array}$ & 0.204 & 2 & 0.102 & 0.209 & 0.812 \\
\hline & $\begin{array}{l}\text { Within } \\
\text { Groups }\end{array}$ & 204.357 & 417 & 0.490 & - & - \\
\hline & Total & 204.562 & 419 & - & - & - \\
\hline \multirow{3}{*}{ Grade level } & $\begin{array}{l}\text { Between } \\
\text { Groups }\end{array}$ & 0.496 & 1 & 0.496 & 1.017 & 0.314 \\
\hline & $\begin{array}{l}\text { Within } \\
\text { Groups }\end{array}$ & 204.066 & 418 & 0.488 & - & - \\
\hline & Total & 204.562 & 419 & - & - & - \\
\hline \multirow{3}{*}{ School type } & $\begin{array}{l}\text { Between } \\
\text { Groups }\end{array}$ & 2.124 & 3 & 0.708 & 1.455 & .226 \\
\hline & $\begin{array}{l}\text { Within } \\
\text { Groups }\end{array}$ & 202.438 & 416 & 0.487 & - & - \\
\hline & Total & 204.562 & 419 & - & - & - \\
\hline \multirow{3}{*}{ Mother's job } & $\begin{array}{l}\text { Between } \\
\text { Groups }\end{array}$ & 1.998 & 3 & 0.666 & 1.368 & 0.252 \\
\hline & $\begin{array}{l}\text { Within } \\
\text { Groups }\end{array}$ & 202.564 & 416 & 0.487 & - & - \\
\hline & Total & 204.562 & 419 & - & - & - \\
\hline
\end{tabular}




\begin{tabular}{|c|c|c|c|c|c|c|}
\hline \multirow{3}{*}{$\begin{array}{l}\text { University entrance exam's subject } \\
\text { group }\end{array}$} & $\begin{array}{l}\text { Between } \\
\text { Groups }\end{array}$ & 6.592 & 5 & 1.318 & 2.757 & $0.018^{* *}$ \\
\hline & $\begin{array}{l}\text { Within } \\
\text { Groups }\end{array}$ & 197.970 & 414 & 0.478 & - & - \\
\hline & Total & 204.562 & 419 & - & - & - \\
\hline \multirow{3}{*}{ Family monthly income (USD) } & $\begin{array}{l}\text { Between } \\
\text { Groups }\end{array}$ & 4.695 & 5 & 0.939 & 1.945 & 0.086 \\
\hline & $\begin{array}{l}\text { Within } \\
\text { Groups }\end{array}$ & 199.867 & 414 & 0.483 & - & - \\
\hline & Total & 204.562 & 419 & - & - & - \\
\hline
\end{tabular}

* Correlation is significant at the 0.05 level; ${ }^{* *}$ correlation is significant at the 0.01 level; ${ }^{* * *}$ correlation is significant at the 0.001 level.

Appendix C. Robust Tests of Equality of Means

\begin{tabular}{ccccc}
\hline Welch & Statistic & df1 & df2 & Sig. \\
\hline Father's job & 2.523 & 3 & 131.111 & 0.061 \\
\hline Self-evaluation on learning capability & 6.377 & 3 & 29.235 & $0.002^{* *}$ \\
\hline Self-evaluation on English capability & 3.714 & 3 & 117.499 & $0.014{ }^{* *}$ \\
\hline $\begin{array}{l}* \text { Correlation is significant at the } 0.05 \text { level; }{ }^{* *} \text { correlation is significant at the } 0.01 \text { level; } \\
\text { is }{ }^{* *} \text { correlation }\end{array}$
\end{tabular}

\section{References}

1. Tran, T.; Ho, M.-T.; Pham, T.-H.; Nguyen, M.-H.; Nguyen, K.-L.P.; Vuong, T.-T.; Nguyen, T.-H.T.; Nguyen, T.-D.; Nguyen, T.-L.; Khuc, Q.; et al. How Digital Natives Learn and Thrive in the Digital Age: Evidence from an Emerging Economy. Sustainability 2020, 12, 3819, doi:10.3390/su12093819.

2. Le, A.-V.; Do, D.-L.; Pham, D.-Q.; Hoang, P.-H.; Duong, T.-H.; Nguyen, H.N.; Vuong, T.-T.; Nguyen, H.K.T.; Ho, T.M.; La, V.-P.; et al. Exploration of Youth's Digital Competencies: A Dataset in the Educational Context of Vietnam. Data 2019, 4, 69, doi:10.3390/data4020069.

3. Abad-Segura, E.; González-Zamar, M.-D.; Infante-Moro, J.C.; García, G.R. Sustainable Management of Digital Transformation in Higher Education: Global Research Trends. Sustainability 2020, 12, 2107, doi:10.3390/su12052107.

4. Romero-Rodríguez, L.M.; Ramírez-Montoya, M.S.; Aguaded, I. Determining Factors in MOOCs Completion Rates: Application Test in Energy Sustainability Courses. Sustainability 2020, 12, 2893, doi:10.3390/su12072893.

5. Vuong, Q.-H.; Le, A.-V.; La, V.-P.; Vuong, T.-T.; Do, T.-H.; Vuong, H.-M.; Do, D.-L.; Hoang, P.-H.; Thi, H.V.; Ho, T.M.; et al. A Dataset of Vietnamese Junior High School Students' Reading Preferences and Habits. Data 2019, 4, 49, doi:10.3390/data4020049.

6. Morales, E.E. Learning from Success: How Original Research on Academic Resilience Informs what College Faculty Can do to Increase the Retention of Low Socioeconomic Status Students. Int. J. High. Educ. 2014, 3, doi:10.5430/ijhe.v3n3p92.

7. Turner, E.A.; Chandler, M.; Heffer, R.W. The Influence of Parenting Styles, Achievement Motivation, and Self-Efficacy on Academic Performance in College Students. J. Coll. Stud. Dev. 2009, 50, 337-346, doi:10.1353/csd.0.0073.

8. Warner, S.; Murray, G.; Meyer, D. Holiday and school-term sleep patterns of Australian adolescents. J. Adolesc. 2008, 31, 595-608, doi:10.1016/j.adolescence.2007.10.005.

9. Oyemi, S.; Noak, A.; Olakanmi, E.E. Effects of Excessive Usage of Social Networking on Students Learning Habit. In Proceedings of the EdMedia 2015-World Conference on Educational Media and Technology, 2225 June 2015; pp. 523-531.

10. Hemphill, S.; Broderick, D.; Heerde, J. Positive associations between school suspension and student problem behaviour: Recent Australian findings. Trends Issues Crime Crim. Justice 2017, 531, 1.

11. Ko, C.-H.; Yen, C.-F.; Yen, J.-Y.; Yang, M.-J. Psychosocial impact among the public of the severe acute respiratory syndrome epidemic in Taiwan. Psychiatry Clin. Neurosci. 2006, 60, 397-403, doi:10.1111/j.14401819.2006.01522.x. 
12. Zheng, G.; Jimba, M.; Wakai, S. Exploratory Study on Psychosocial Impact of the Severe Acute Respiratory Syndrome (SARS) Outbreak on Chinese Students Living in Japan. Asia Pac. J. Public Health 2005, 17, 124129, doi:10.1177/101053950501700211.

13. Anderson, R.M.; Heesterbeek, H.; Klinkenberg, D.; Hollingsworth, T.D. How will country-based mitigation measures influence the course of the COVID-19 epidemic? Lancet 2020, 395, 931-934, doi:10.1016/S01406736(20)30567-5.

14. Wamsley, L. As Schools Close Because Of Coronavirus, Nearly 300 Million Kids Aren't In Class. NPR, 5 May 2020. Available online: http://www.npr.org/sections/goatsandsoda/2020/03/05/812557984/as-schoolsclose-due-to-coronavirus-nearly-300-million-kids-arent-in-class (acessed on 1 April 2020).

15. Wang, V.; Inoue, M. 'When Can We Go to School?' Nearly 300 Million Children Are Missing Class. New York Times, 4 March 2020. Available online: https://www.nytimes.com/2020/03/04/world/coronavirusschools-closed.html (accessed on 1 April 2020).

16. Kaplan, J.; Frias, L.; Johnsen, M.M. A Third of the Global Population Is on Coronavirus Lockdown-Here's Our Constantly Updated List of Countries and Restrictions. Business Insider, 31 March 2020. Available online: https://www.businessinsider.com/countries-on-lockdown-coronavirus-italy-2020-3 (accessed on 1 April 2020).

17. Oranburg, S. Distance Education in the Time of Coronavirus: Quick and Easy Strategies for Professors. SSRN Papers. 2020. Available online: https://papers.ssrn.com/sol3/papers.cfm?abstract_id=3553911 (accessed on 1 April 2020).

18. VPAL. Teaching Remotely; Harvard's Office of the Vice Provost for Advances in Learning; Harvard University: Cambridge, MA, USA, 23 March 2020. Available online: https://www.harvard.edu/coronavirus/teach-remotely/ (accessed on 1 Apr 2020).

19. Cambridge University. COVID-19 Resources and Information; Cambridge University Press: Cambridge, UK, 2020.

20. Hoang, A.-D.; Nguyen, Q.N.; Nguyen, C.L.; Dao, Q.A.; Doan, P.T.T.; Dinh, T.T.; Ta, H.T.; Quach, L.A.; Tran, D.H. Sổ tay Nâng cao sức khoẻ tinh thần trong mùa dịch. In Handbook of Elevating Mental Health during Disease; EdArXiv Preprints: Ha Noi, Vietnam, 2020.

21. Mental Health America. Mental Health and COVID-19 - Information and Resources; Mental Health America: Alexandria, VA, USA. 25 March 2020. Available online: http://mhanational.org/covid19 (accessed on 1 April 2020)

22. National Alliance on Mental Illness. Available online: https:/www.nami.org/getattachment/AboutNAMI/NAMI-News/2020/NAMI-Updates-on-the-Coronavirus/COVID-19-Updated-Guide-1.pdf (accessed on 1 April 2020).

23. Elseviers. Novel Coronavirus Information Center; Elsevier: Amsterdam, The Netherlands, 2020. Available online: https://www.elsevier.com/connect/coronavirus-information-center (accessed on 20 March 2020).

24. Hachman, M. Microsoft's Solution for COVID-19 Is a Free Teams Subscription for Six Months; PCWorld: San Francisco, CA, USA 2020. Available online: https://www.pcworld.com/article/3530374/microsofts-solutionfor-covid-19-is-a-free-teams-subscription-for-six-months.html (accessed on 1 April 2020).

25. La, V.-P.; Pham, T.-H.; Ho, M.-T.; Nguyen, M.-H.; P. Nguyen, K.-L.; Vuong, T.-T.; Nguyen, H.-K.T.; Tran, T.; Khuc, Q.; Ho, M.-T.; Vuong, Q.-H. Policy Response, Social Media and Science Journalism for the Sustainability of the Public Health System Amid the COVID-19 Outbreak: The Vietnam Lessons. Sustainability 2020, 12, 2931.

26. Nguyen, T. Tất cả các địa phương đã cho học sinh nghỉ học ngừa dịch virus Corona [All provinces announce school closure to prevent coronavirus disease]. Thanh nien Newspaper, 6 February 2020. Available online: hhttp://thanhnien.vn/giao-duc/tat-ca-cac-dia-phuong-da-cho-hoc-sinh-nghi-hoc-ngua-dich-viruscorona-1179441.html (accessed on 20 March 2020).

27. Tran, P. Bộ Y tế khuyến cáo khi đi học trở lại. [Ministry of Health suggests to re-open schools]. Giao duc Newspaper, 14 February 2020. Available online: http:// giaoduc.net.vn/suc-khoe-hoc-duong/bo-y-tekhuyen-cao-khi-di-hoc-tro-lai-post207100.gd (accessed on 20 March 2020).

28. Tuoi Tre, Thêm tỉnh, thành cho học sinh nghỉ tiếp 1-2 tuần. [More provinces and cities let students stay at home for 1 2 more weeks]. Tuoi Tre Newspaper, 28 February 2020. Available online: https://tuoitre.vn/themtinh-thanh-cho-hoc-sinh-nghi-tiep-1-2-tuan-20200228100209705.htm (accessed on 20 March 2020).

29. Vuong, Q.H.; Tran, T. The Vietnamese Social Sciences at a Fork in the Road; Sciendo: Warsaw, Poland, 2019. 
30. Nguyen, M.H.; Ho, M.T.; Nguyen, Q.Y.T.; Vuong, Q.H. A Dataset of Students' Mental Health and HelpSeeking Behaviors in a Multicultural Environment. Data 2019, 4, 124, doi:10.3390/data4030124.

31. Le, T.-T.-H.; Tran, T.; Trinh, T.-P.-T.; Nguyen, C.-T.; Nguyen, T.-P.-T.; Vuong, T.-T.; Thi, H.V.; Quynh, B.D.; Vuong, H.-M.; Hoang, P.-H.; et al. Reading Habits, Socioeconomic Conditions, Occupational Aspiration and Academic Achievement in Vietnamese Junior High School Students. Sustainability 2019, 11, 5113, doi:10.3390/su11185113.

32. Credé, M.; Kuncel, N.R. Study Habits, Skills, and Attitudes: The Third Pillar Supporting Collegiate Academic Performance. Perspect. Psychol. Sci. 2008, 3, 425-453, doi:10.1111/j.1745-6924.2008.00089.x.

33. Adejumo, S.G. Influence of Study Habit and Types of Home on Students' Academic Performance in Ogbomoso North Local Government of Oyo State, 2018. Available online: https://www.academia.edu/38528723/INFLUENCE_OF_STUDY_HABIT_AND_TYPES_OF_HOME_ON_ STUDENTS_ACADEMIC_PERFORMANCE_IN_OGBOMOSO_NORTH_LOCAL_GOVERNMENT_OF_ OYO_STATE (accessed on 20 May 2020)

34. Maiyo, J.; Siahi, E.A. Study of the relationship between study habits and academic achievement of students: A case of Spicer Higher Secondary School, India. Int. J. Educ. Admin. Policy Stud. 2015, 7, 134-141, doi:10.5897/IJEAPS2015.0404.

35. Ozsoy, G.; Aysel, M.; Temur, T. Metacognition, study habits and attitudes. Int. Electron. J. Elem. Educ. 2017, 2, 154-166.

36. Bilge, F.; Dost, M.T.; Çetin, B. Factors Affecting Burnout and School Engagement among High School Students: Study Habits, Self- Efficacy Beliefs, and Academic Success. Educ. Sci. Theory Pr. 2014, doi:10.12738/estp.2014.5.1727.

37. Ebele, U.F.; Olofu, P.A. Study habit and its impact on secondary school students academic performance in biology in the Federal Capital Territory, Abuja. Educ. Res. Rev. 2017, 12, 583-588, doi:10.5897/ERR2016.3117.

38. Illahi, B.o.; Khandai, H. Academic Achievements and Study Habits of College Students of District Pulwama. J. Educ. Prac. 2015, 6, 1-6.

39. Yu, D.D. How Much Do Study Habits, Skills, and Attitudes Affect Student Performance in Introductory College Accounting Courses? New Horiz. Educ. 2011, 59, 1-15.

40. Nonis, S.A.; Hudson, G.I. Performance of College Students: Impact of Study Time and Study Habits. J. Educ. Bus. 2010, 85, 229-238, doi:10.1080/08832320903449550.

41. Numan, A.; Hasan, S.S. Effect of Study Habits on Test Anxiety and Academic Achievement of Undergraduate Students. J. Res. Reflect. Educ. 2017, 11, 1-14.

42. Wagner, P.; Schober, B.; Spiel, C. Time students spend working at home for school. Learn. Instr. 2008, 18, 309-320, doi:10.1016/j.learninstruc.2007.03.002.

43. Vuong, Q.H. The (ir)rational consideration of the cost of science in transition economies. Nat. Hum. Behav. 2018, 2, 5, doi:10.1038/s41562-017-0281-4.

44. Kalenkoski, C.M.; Pabilonia, S.W. Does high school homework increase academic achievement? Education Economics 2017, 25, 45-59, doi:10.1080/09645292.2016.1178213.

45. Plant, E.A.; Ericsson, K.A.; Hill, L.; Asberg, K. Why study time does not predict grade point average across college students: Implications of deliberate practice for academic performance. Contemp. Educ. Psychol. 2005, 30, 96-116, doi:10.1016/j.cedpsych.2004.06.001.

46. Bergin, D.A. Student Goals for Out-of-School Learning Activities. J. Adolesc. Res. 1989, 4, 92-109, doi:10.1177/074355488941007.

47. Wagner, P.; Schober, B. Time students spend working at home for school: A hierarchical model analysis. In C-crcs Volume I BOOK; Future Academy: London, UK, 2013; pp. 45-53.

48. Larson, R.W.; Verma, S. How children and adolescents spend time across the world: Work, play, and developmental opportunities. Psychol. Bull. 1999, 125, 701-736, doi:10.1037/0033-2909.125.6.701.

49. Ke, F.; Kwak, D. Online learning across ethnicity and age: A study on learning interaction participation, perception, and learning satisfaction. Comput. Educ. 2013, 61, 43-51, doi:10.1016/j.compedu.2012.09.003.

50. Mueller, C.W.; Parcel, T.L. Measures of Socioeconomic Status: Alternatives and Recommendations. Child Dev. 1981, 52, 13, doi:10.2307/1129211.

51. Hauser, R.M. Measuring Socioeconomic Status in Studies of Child Development. Child Dev. 1994, 65, 15411545, doi:10.1111/j.1467-8624.1994.tb00834.x.

52. Coleman, J.S. Social capital in the creation of human capital. Am. J. Sociol. 1988, 94, 95-120. 
53. Duncan, G.J.; Gunn, J.B. Income effects across the life span: Integration and interpretation. In Consequences of Growing up Poor; Duncan, G.J., Gunn, J.B., Eds.; Russell Sage Foundation: New York, NY, USA, 1997; pp. 596-610.

54. Ensminger, M.E.; Fothergill, K. A decade of measuring SES: What it tells us and where to go from here. Socioecon. Status Parent. Child Dev. 2003, 13, 27.

55. Hauser, R.M.; Huang, M.-H. Verbal Ability and Socioeconomic Success: A Trend Analysis. Soc. Sci. Res. 1997, 26, 331-376, doi:10.1006/ssre.1997.0604.

56. Bollen, K.A.; Glanville, J.L.; Stecklov, G. Socioeconomic Status and Class in Studies of Fertility and Health in Developing Countries. Ann. Rev. Sociol. 2001, 27, 153-185, doi:10.1146/annurev.soc.27.1.153.

57. Blanden, J.; Gregg, P. Family Income and Educational Attainment: A Review of Approaches and Evidence for Britain. Oxford Rev. Econ. Policy 2004, 20, 245-263, doi:10.1093/oxrep/grh014.

58. Sirin, S.R. Socioeconomic Status and Academic Achievement: A Meta-Analytic Review of Research. Rev. Educ. Res. 2005, 75, 417-453, doi:10.3102/00346543075003417.

59. Tran, T.; Le, T.; Nguyen T.-H.; Pham, A.-G.; Thi, H.V.; Vuong, Q.-H.; Hoang, P.-H.; Ho, T.M.; Nguyen, M.H. The Relationship between Birth Order, Sex, Home Scholarly Culture and Youths' Reading Practices in Promoting Lifelong Learning for Sustainable Development in Vietnam. Sustainability 2019, 11, 4389, doi:10.3390/su11164389.

60. Hauser, R.M.; Warren, J.R. Socioeconomic Indexes for Occupations: A Review, Update, and Critique. Sociol. Methodol. 1997, 27, 177-298, doi:10.1111/1467-9531.271028.

61. Chevalier, A.; Harmon, C.; Sullivan, V.O.; Walker, I. The impact of parental income and education on the schooling of their children. IZA J. Labor Econ. 2013, 2, 8, doi:10.1186/2193-8997-2-8.

62. Duncan, O.D. A Socioeconomic Index for all Occupations. In Occupations and Social Status; Reiss, A.J., Jr., Ed.; The Free Press of Glencoe, Inc.: New York, NY, USA, 1963; pp. 109-138.

63. Robert, D.F.; Foehr, U.G.; Rideout, V.J. Generation M: Media in the Lives of 8-18 Year-olds; Kaiser Family Foundation: San Francisco, CA, USA, 2005.

64. Rideout, V.J.; Foehr, U.G.; Robert, D.F. Generation M2: Media in the Lives of 8 to 18 Year-Olds; Kaiser Family Foundation: San Francisco, CA, USA, 2010.

65. McLoyd, V.C. Socioeconomic disadvantage and child development. Am. Psychol. 1998, 53, 185-204, doi:10.1037/0003-066X.53.2.185.

66. Marks, G.N.; Cresswell, J.; Ainley, J. Explaining socioeconomic inequalities in student achievement: The role of home and school factors. Educ. Res. Eval. 2006, 12, 105-128, doi:10.1080/13803610600587040.

67. Henderson, A.T. The Evidence Continues to Grow: Parent Involvement Improves Student Achievement; National Committee for Citizens in Education: Columbia, MD, USA, 1987.

68. Ali, A.; Ali, Z.; Naz, R. Study Habits and Education Planning: A Case Study of Comparison of Private and Public Sector Schools. Dialogue 2012, 7, 98.

69. Keith, T.Z.; Keith, P.B.; Quirk, K.J.; Sperduto, J.; Santillo, S.; Killings, S. Longitudinal Effects of Parent Involvement on High School Grades. J. Sch. Psychol. 1998, 36, 335-363, doi:10.1016/S0022-4405(98)00008-9.

70. Calderon, R. Parental Involvement in Deaf Children's Education Programs as a Predictor of Child's Language, Early Reading, and Social-Emotional Development. J. Deaf Stud. Deaf Educ. 2000, 5, 140-155, doi:10.1093/deafed/5.2.140.

71. McNeal, R.B. Differential effects of parental involvement on cognitive and behavioral outcomes by socioeconomic status. J. Socio-Econ. 2001, 30, 171-179, doi:10.1016/S1053-5357(00)00100-1.

72. Grolnick, W.S.; Benjet, C.; Kurowski, C.O.; Apostoleris, N.H. Predictors of parent involvement in children's schooling. J. Educ. Psychol. 1997, 89, 538-548, doi:10.1037/0022-0663.89.3.538.

73. Evans, M.D.R.; Kelley, J.; Sikora, J.; Treiman, D.J. Family scholarly culture and educational success: Books and schooling in 27 nations. Res. Soc. Stratif. Mobil. 2010, 28, 171-197, doi:10.1016/j.rssm.2010.01.002.

74. Carter, S. The Impact of Parent/Family Involvement of Student Outcomes: An Annotated Bibliography of Research from the Past Decade. Consort. Appropr. Disput. Resolut. Spec. Educ. 2002. Available online: https:/oaklandliteracycoalition.org/wp-content/uploads/2016/12/Impact-Family-Involvement.pdf (accessed on 10 April 2020).

75. Pomerantz, E.M.; Moorman, E.A.; Litwack, S.D. The How, Whom, and Why of Parents' Involvement in Children's Academic Lives: More Is Not Always Better. Rev. Educ. Res. 2007, 77, 373-410, doi:10.3102/003465430305567. 
76. Castro, M.; Expósito-Casas, E.; López-Martín, E.; Lizasoain, L.; Navarro-Asencio, E.; Gaviria, J.L. Parental involvement on student academic achievement: A meta-analysis. Educ. Res. Rev. 2015, 14, 33-46, doi:10.1016/j.edurev.2015.01.002.

77. Hoover-Dempsey, K.V.; Battiato, A.C.; Walker, J.; Reed, R.P.; DeJong, J.M.; Jones, K.P. Parental Involvement in Homework. Educ. Psychol. 2001, 36, 195-209, doi:10.1207/S15326985EP3603_5.

78. Epstein, J.b.; Sanders, M.G.; Simon, B.S.; Salinas, K.C.; Jansorn, N.R.; Voorhis, F.L.V. School, Family, and Community Partnerships: Your Handbook for Action; Corwin Press, Inc.: Thousand Oaks, CA, USA, 2002.

79. Cotton, K.; Wikelund, K.R. Parent involvement in education. Sch. Improv. Res. Series 1989, 6, 17-23, Available online: https://educationnorthwest.org/sites/default/files/resources/parent-involvement-ineducation-508.pdf (accessed on 26 March 2020).

80. Epstein, J.L.; Sheldon, S.B. Present and Accounted for: Improving Student Attendance through Family and Community Involvement. J. Educ. Res. 2002, 95, 308-318, doi:10.1080/00220670209596604.

81. Hoff, E. The Specificity of Environmental Influence: Socioeconomic Status Affects Early Vocabulary Development Via Maternal Speech. Child Dev. 2003, 74, 1368-1378, doi:10.1111/1467-8624.00612.

82. Mezzacappa, E. Alerting, Orienting, and Executive Attention: Developmental Properties and Sociodemographic Correlates in an Epidemiological Sample of Young, Urban Children. Child Dev. 2004, 75, 1373-1386, doi:10.1111/j.1467-8624.2004.00746.x.

83. Topor, D.R.; Keane, S.P.; Shelton, T.L.; Calkins, S.D. Parent Involvement and Student Academic Performance: A Multiple Mediational Analysis. J. Prev. Interv. Community 2010, 38, 183-197, doi:10.1080/10852352.2010.486297.

84. Marchant, G.J.; Paulson, S.E.; Rothlisberg, B.A. Relations of middle school students' perceptions of family and school contexts with academic achievement. Psychol. Sch. 2001, 38, 505-519, doi:10.1002/pits.1039.

85. Cooper, H.; Lindsay, J.J.; Nye, B. Homework in the Home: How Student, Family, and Parenting-Style Differences Relate to the Homework Process. Contemp. Educ. Psychol. 2000, 25, 464-487, doi:10.1006/ceps.1999.1036.

86. Xu, J.; Corno, L. Family Help and Homework Management Reported by Middle School Students. Element. Sch. J. 2003, 103, 503-517, doi:10.1086/499737.

87. Gonzalez-DeHass, A.R.; Willems, P.P.; Holbein, M.F.D. Holbein, Examining the Relationship Between Parental Involvement and Student Motivation. Educ. Psychol. Rev. 2005, 17, 99-123, doi:10.1007/s10648-0053949-7.

88. DiPrete, T.A.; Eirich, G.M. Cumulative Advantage as a Mechanism for Inequality: A Review of Theoretical and Empirical Developments. Ann. Rev. Sociol. 2006, 32, 271-297, doi:10.1146/annurev.soc.32.061604.123127.

89. Elliot, A.J.; Dweck, C.S. Handbook of Competence and Motivation; Guilford Press.and classroom effects: New York, NY, USA, 2005.

90. Anderman, E.M.; Young, A.J. Motivation and strategy use in science: Individual differences and classroom effects. J. Res. Sci. Teach. 1994, 31, 811-831, doi:10.1002/tea.3660310805.

91. Middleton, M.J.; Midgley, C. Avoiding the demonstration of lack of ability: An underexplored aspect of goal theory. J. Educ. Psychol. 1997, 89, 710-718, doi:10.1037/0022-0663.89.4.710.

92. Hutchins, A.M. The Relationship between Goal Orientation and Gender Roles; Western Kentucky University: Bowling Green, KY, USA, 2009.

93. Makarova, E.; Aeschlimann, B.; Herzog, W. The Gender Gap in STEM Fields: The Impact of the Gender Stereotype of Math and Science on Secondary Students' Career Aspirations. Front. Educ. 2019, 4, doi:10.3389/feduc.2019.00060.

94. Vuong, Q.H.; Hang, P.T.; Tran, T.; Vuong, T.-T.; Cuong, N.M.; Linh, N.P.K.; La, V.-P.; Ho, M.-T. STEM education and outcomes in Vietnam: Views from the social gap and gender issues. SSRN Electron. J. 2020, doi:10.2139/ssrn.3543346.

95. Bejanyan, K.; Marshall, T.C.; Ferenczi, N. Associations of Collectivism with Relationship Commitment, Passion, and Mate Preferences: Opposing Roles of Parental Influence and Family Allocentrism. PLoS ONE 2015, 10, e0117374, doi:10.1371/journal.pone.0117374.

96. Sawitri, D.R.; Creed, P.; Zimmer-Gembeck, M.J. Parental influences and adolescent career behaviours in a collectivist cultural setting. Int. J. Educ. Vocat. Guid. 2014, 14, 161-180, doi:10.1007/s10775-013-9247-x. 
97. Garcia, P.R.J.M.; Restubog, S.L.D.; Toledano, L.S.; Tolentino, L.; Rafferty, A. Differential Moderating Effects of Student- and Parent-Rated Support in the Relationship Between Learning Goal Orientation and Career Decision-Making Self-Efficacy. J. Career Assess. 2012, 20, 22-33, doi:10.1177/1069072711417162.

98. Sawitri, D.R.; Creed, P.A. Creed, Collectivism and Perceived Congruence with Parents as Antecedents to Career Aspirations. J. Career Dev. 2017, 44, 530-543, doi:10.1177/0894845316668576.

99. General Statistics Office of Vietnam. General Education Statistics. GSO. 2020. Available online: https://www.gso.gov.vn/default_en.aspx?tabid=782 (accessed on 26 March 2020).

100. Trung, T.; Hoang, A.-D.; Nguyen, T.T.; Dinh, V.-H.; Nguyen, Y.-C.; Pham, H.-H. Dataset of Vietnamese student's learning habits during COVID-19. Data Brief 2020, 30, 105682, doi:10.1016/j.dib.2020.105682

101. Vietnam Ministry of Education and Training, Official dispatch 793/BGDĐT-GDTrH on enhancing Teaching on the Internet and on Television during the Time of Preventing and Fighting against Covid-19. 2020. Available online: https:/e-ict.gov.vn/laws/detail/CV-so-793-BGDDT-GDTrH-ngay-12-3-2020-ve-viectang-cuong-day-hoc-qua-internet-tren-truyen-hinh-trong-thoi-gian-nghi-hoc-de-phong-chong-Covid-19740/ (accessed on 25 March 2020).

102. Fujita, K. The effects of extracurricular activities on the academic performance of junior high students. Undergrad. Res. J. Hum. Sci. 2006, 5, 1-16.

103. Bandura, A.; Barbaranelli, C.; Caprara, G.V.; Pastorelli, C. Multifaceted Impact of Self-Efficacy Beliefs on Academic Functioning. Child Dev. 1996, 67, 1206, doi:10.2307/1131888.

104. Bassi, M.; Steca, P.; Fave, A.D.; Caprara, G.V. Academic Self-Efficacy Beliefs and Quality of Experience in Learning. J. Youth Adolesc. 2007, 36, 301-312, doi:10.1007/s10964-006-9069-y.

105. Schunk, D.H. Goal Setting and Self-Efficacy during Self-Regulated Learning. Educ. Psychol. 1990, 25, 71-86, doi:10.1207/s15326985ep2501_6.

106. Sterling, S. Sustainable education-towards a deep learning response to unsustainability. Policy Prac. A Dev. Educ. Rev. 2008, 6, 63-68.

(C) 2020 by the authors. Licensee MDPI, Basel, Switzerland. This article is an open access article distributed under the terms and conditions of the Creative Commons Attribution (CC BY) license (http://creativecommons.org/licenses/by/4.0/). 